\title{
Performance of Twelve Mass Transfer Based Reference Evapotranspiration Models under Humid Climate
}

\author{
Koffi Djaman ${ }^{*}$, Komlan Koudahe², Mamadou Sall ${ }^{3}$, Isa Kabenge ${ }^{4}$, Daran Rudnick ${ }^{5}$, Suat Irmak ${ }^{5}$ \\ ${ }^{1}$ Department of Plant and Environmental Sciences, New Mexico State University, Agricultural Science Center, Farmington, \\ USA \\ ${ }^{2}$ ADA Consulting Africa, Lomé, Togo \\ ${ }^{3}$ Research Scientist, Institut Senegalais de Recherches Agricoles, Centre de Saint Louis, Saint Louis, Sénégal \\ ${ }^{4}$ Department of Agricultural and Biosystems Engineering, Makerere University, Kampala, Uganda \\ ${ }^{5}$ Department of Biological Systems Engineering, University of Nebraska-Lincoln, Chase Hall, Lincoln, USA \\ Email: *kdjaman@nmsu.edu
}

How to cite this paper: Djaman, K., Koudahe, K., Sall, M., Kabenge, I., Rudnick, D. and Irmak, S. (2017) Performance of Twelve Mass Transfer Based Reference Evapotranspiration Models under Humid Climate. Journal of Water Resource and Protection, 9, 1347-1363.

https://doi.org/10.4236/jwarp.2017.912086

Received: September 3, 2017

Accepted: November 13, 2017

Published: November 16, 2017

Copyright $\odot 2017$ by authors and Scientific Research Publishing Inc This work is licensed under the Creative Commons Attribution International License (CC BY 4.0).

http://creativecommons.org/licenses/by/4.0/

\begin{abstract}
Reference evapotranspiration is very important parameter in the hydrological, agricultural and environmental studies and is accurately estimated by the FAO Penman-Monteith equation (FAO-PM) under different climatic conditions. However, due to data requirement of the FAO-PM equation, there is a need to investigate the applicability of alternative ETo equations under limited data. The objectives of this study were to evaluate twelve mass transfer based reference evapotranspiration equations and determine the impact of ETo equation on long term water management sustainability in Tanzania and Kenya. The results showed that the Albrecht, Brockamp-Wenner, Dalto, Meyer, Rohwer and Oudin ETo equations systematically overestimated the daily ETo at all weather stations with relative errors that varied from $34 \%$ to $94 \%$ relative to the FAO-PM ETo estimates. The Penman, Mahringer, Trabert, and the Romanenko equations performed best across Tanzania and the South Western Kenya with root mean squared errors ranging from 0.98 to $1.48 \mathrm{~mm} / \mathrm{day}$, which are relatively high and mean bias error (MBE) varying from -0.33 to $0.02 \mathrm{~mm} /$ day and the absolute mean error (AME) from 0.79 to $1.16 \mathrm{~mm} /$ day. For sustainable water management, the Trabert equation could be adopted at Songea, the Mahringer equation at Tabora, the Dalton and/or the Rohwer equations at Eldoret, the Romanenko equation at Dodoma, Songea and Eldoret. However, regional calibration of the most performing equation could improve water management at regional level.
\end{abstract}

\section{Keywords}

Reference Evapotranspiration, Mass Transfer, Eastern Africa, Water 
Management

\section{Introduction}

Evapotranspiration is an important parameter for climatological and hydrological studies as well as for agricultural water resources management [1] [2]. The accuracy of reference evapotranspiration (ETo) estimates directly feeds into the decision making process for regional water resources planning and, especially under semi-arid and arid conditions. Different methods of ETo estimation have been developed ranging from direct measurements from a reference crop [3] to computation from weather data such as temperature based models [3] [4], radiation based models [3] [5], and combination-based energy balance models [6] [7]. Numerous worldwide studies have shown that the FAO-56 Penman-Monteith (FAO-PM) model is the most accurate one under different climatic conditions across the world [6]-[13] and had been adopted and recommended for ETo estimation [6] [7]. However, FAO-PM model requires maximum and minimum temperature, minimum and maximum relative humidity, solar radiation, and wind speed data to be run and these weather datasets are usually incomplete and/or not available in most developing countries. This data demand is the main constraint of use of the FAO-PM in locations where climate data is limited [14]-[17]. Therefore, the application of ETo equations with fewer meteorological parameters requirements is necessary under situations where more complete weather data are lacking. However, the evaluation of the suitability for each of the alternative ETo equations to determine the most suitable for particular locations using FAO-PM model as reference is required for the East Africa Region prior to their application.

[18] indicated that the Turc ETo equation is recommended for estimating ETo using measured maximum and minimum air temperature and estimated radiation in Florida. From a cross comparison of 31 ETo methods, [19] showed that the five best methods as compared to the FAO-PM model were the two radiation based developed by the authors, the temperature based Blaney-Criddle [20], the Hargreaves-M4 equations [5] and the Snyder pan evaporation based equation [21]. [22] reported that Hansen and Turc equations were the most useful with the least average monthly error from the evaluation of 13 empirical reference potential evapotranspiration equations in Greece. Regarding the importance of accurate estimation of ETo by the Penman-Monteith method in data-limiting conditions, the recent studies [23] [24] have managed to simplify the estimation method with good performance and accuracy, even when the available data is very limited. The applicability of several other different ETo methods has been evaluated under different climatic conditions depending on their complexity and the required climatic variables data and their availability [25]-[30]. [2] evaluated sixteen ETo models and showed that the Valiantzas, Trabert, Romanenko, 
Schendel and Mahringer equations were the promising equations that could be used for ETo estimation under the Sahelian conditions in the Senegal River Valley. [13] reported that Hargreaves' method was the most accurate among five equations for estimating ETo under a semi-arid climate in Spain. Hargreaves equation was also the best model to estimate ETo in eastern arid and semiarid regions of Iran [31]. [32] indicated that the Turc equation was the best in the Western Balkans in Europe. [22] reported that Hansen and Turc equations were the most useful for ETo estimation in Greece. [33] evaluated 24 ETo equation in Greece under a Mediterranean forest environmental conditions and indicated that the adaptability of some empirical equations and the best performing ones were the Copais, original Hargreaves, and one of the Valiantzas' equations with very high equation efficiency and agreement indexes. [34] reported that Berti ETo equation was the best alternative of the FAO Penman-Monteith ETo equation under limited data condition in China. Three mass transfer ETo equations of Trabert, Mahringer, and Albrecht had shown good performance as they were calibrated to the local semiarid climatic conditions in the Senegal River Valley [35]. The mass transfer based Penman ETo equation performed as the best ETo equation among several equations in Malaysia [36]. Similar results were reported by [37] using data from eight weather stations across Burkina Faso for the 1998-2012 period. Different sets of equations have been tested in different regions and sub-regions under different climatic conditions including Canada [38], Iran [28] [39] [40], China [41], Poland [42], Southeast Australia [43], Senegal [2], and in Burkina Faso [44].

While the aforementioned studies have been conducted at different parts of the world, extremely limited data and information is available on this very important topic in Eastern Africa, particularly in Tanzania and Kenya. Therefore, it is critical to assess the applicability of ETo models for sustainable water management. Thus, the objectives of this study were to: 1) evaluate twelve mass transfer based ETo equations with comparison to the FAO-PM method, and 2) determine the impact of ETo equation on long term water management sustainability in Tanzania and Kenya.

\section{Materials and Methods}

\subsection{Data Source and Type}

Climatic data required for evaluating the FAO-PM ETo equation and the selected ETo models were collected at five weather stations across Tanzania and four weather stations in South-Western Kenya, for the period of 1998-2012. Maximum and minimum air temperature (Tmax and Tmin), maximum and minimum relative humidity (RHmax and RHmin), solar radiation $(R s)$ and wind speed ( $u 2$ ) were collected from Dodoma, Morogoro, Songea, Kilimanjaro, and Tabora in Tanzania; and Nakuru, Jomo Kenyatta, Kisumu, and Eldoret in Kenya with the geographic coordinates presented in Table 1. Tanzania is characterized by tropical climate with hot and humid coastal areas and cool and temperate 
Table 1. Geographic coordinates of the nine weather observatories.

\begin{tabular}{ccccc}
\hline Country & Weather station & $\begin{array}{c}\text { Latitude } \\
\text { (Degree North) }\end{array}$ & $\begin{array}{c}\text { Longitude } \\
\text { (Degree East) }\end{array}$ & Altitude(m) \\
\hline \multirow{3}{*}{ Tanzania } & Dodoma & -6.17 & 35.77 & 1120 \\
& Morogoro & -6.83 & 37.65 & 526 \\
& Songea & -10.67 & 36 & 1036 \\
& Kilimanjaro & -3.43 & 37.07 & 896 \\
& Tabora & -5.08 & 33 & 1182 \\
\hline \multirow{3}{*}{ Kenya } & Nakuru & -0.16 & 36.6 & 1901 \\
& Jomo Kenyatta & -1.32 & 36.92 & 1624 \\
& Kisumu & -0.09 & 34.73 & 1146 \\
& Eldoret & 0.48 & 35.3 & 2120 \\
\hline
\end{tabular}

northwestern highlands. The northern and eastern areas of Tanzania experience two distinct rain seasons; the short occurring during October to December and the long rains from March to May. However, the southern, western, and central parts of the country experience one wet season that continues from October through to April or May. The central plateau in Tanzania tends to be dry and arid throughout the year. Kenya's spatial extent lies astride the equator and thus characterized by a tropical climate. Similar to Tanzania, Kenya's coastal zone is hot and humid, has a temperate inland, very dry in the north and northeastern areas and the western area is hot and wet throughout the year [45] [46]. Most of Kenya has a bimodal rainfall pattern, with the longer season occurring during March to May (MAM) and the shorter season during October to December (OND). Some areas in the western and central parts of the Kenyan Rift Valley experience a tri-modal rainfall pattern. The climate is influenced by systems such as the migration of Inter-Tropical Convergence Zone (ITCZ) from south to north and vice versa, Sub Tropical High Pressure systems (STHP), El Niño/Southern Oscillation(ENSO), Monsoon winds, tropical cyclones, the Indian Ocean, Lake Victoria circulation and the topography [46] [47] [48].

\subsection{Reference Evapotranspiration Models}

1) Penman-Monteith model (FAO-PM)

Daily reference evapotranspiration was computed using the Penman-Monteith (FAO-PM) equation (ETo-Ref) [6]. The Penman-Monteith ETo equation with fixed stomatal resistance values for grass surface is:

$$
\mathrm{ETo}=\frac{0.408 \Delta(R n-G)+(\gamma C n u 2 /(T+273))(e s-e a)}{\Delta+\gamma(1+C d u 2)}
$$

where: ETo is the reference evapotranspiration ( $\mathrm{mm} /$ day), $\Delta$ is the slope of saturation vapor pressure versus air temperature curve $\left(\mathrm{kPa} \cdot{ }^{\circ} \mathrm{C}^{-1}\right), R n=$ net radiation at the crop surface $\left(\mathrm{MJ} \cdot \mathrm{m}^{-2} \cdot \mathrm{d}^{-1}\right), G=$ soil heat flux density at the soil surface $\left(\mathrm{MJ} \cdot \mathrm{m}^{-2} \cdot \mathrm{d}^{-1}\right), T=$ mean daily air temperature at $1.5-2.5 \mathrm{~m}$ height $\left({ }^{\circ} \mathrm{C}\right), u 2=$ 
mean daily wind speed at $2 \mathrm{~m}$ height $\left(\mathrm{m} \cdot \mathrm{s}^{-1}\right)$, $e s=$ the saturation vapor pressure at $1.5-2.5 \mathrm{~m}$ height $(\mathrm{kPa})$, ea = the actual vapor pressure at $1.5-2.5 \mathrm{~m}$ height $(\mathrm{kPa})$, es - ea = saturation vapor pressure deficit $(\mathrm{kPa}), \gamma=$ psychrometric constant $\left(\mathrm{kPa} \cdot{ }^{\circ} \mathrm{C}^{-1}\right), C n=900^{\circ} \mathrm{C} \cdot \mathrm{mm} \cdot \mathrm{s}^{3} \cdot \mathrm{Mg}^{-1} \cdot \mathrm{d}^{-1}, C d=0.34 \mathrm{~s} \cdot \mathrm{m}^{-1}$ for grass, $\gamma$ is the psychrometric constant $\left(\mathrm{kPa} \cdot{ }^{\circ} \mathrm{C}^{-1}\right)$. All parameters necessary for computing ETo were computed according the procedure developed in FAO-56 by [6].

Twelve mass transfer ETo equations were selected based on their applicability to regions with similar characteristics and compared with the FAO-PM equation for their accuracy in estimating daily ETo and to determine the best performing equations at each weather station.

2) [49]

$$
\mathrm{ETo}=(3.648+0.7223 u)(e s-e a)
$$

3) $[50]$

$$
\mathrm{ETo}=3.075 \sqrt{u}(e s-e a)
$$

4) $[51]$

$$
\mathrm{ETo}=(0.375+0.05026 u)(e s-e a)
$$

5) $[52]$

$$
\mathrm{ETo}=(3.3+0.891 u)(e s-e a)
$$

6) $[53]$

$$
\text { ETo }=0.35(1+0.98 / 100 u)(e s-e a)
$$

7) $[54]$

$$
\mathrm{ETo}=(0.1005+0.297 u)(e s-e a)
$$

8) $[55]$

$$
\mathrm{ETo}=0.0018(T a+25)^{2}(100-R H)
$$

9) $[56]$

$$
\mathrm{ETo}=0.543 u^{0.456}(e s-e a)
$$

10) [57]

$$
\mathrm{ETo}=(1.298+0.934 u)(e s-e a)
$$

11) $[58]$

$$
\mathrm{ETo}=2.5(e m s-e a)
$$

12) $[59]$

$$
\mathrm{ETo}=0.15072 * \sqrt{3.6 u} *(e s-e a)
$$

13) $[60]$

$$
\text { ETo }=4.5 *\left[1+\left(\frac{\text { Tmean }}{25}\right)\right]^{2} *\left(1-\frac{e a}{e s}\right)
$$

where ETo is in $\mathrm{mm} /$ day, ems, ea and es in $\mathrm{kPa}, u$ in $\mathrm{m} / \mathrm{s}$, Tmean is mean daily 
temperature in $\left({ }^{\circ} \mathrm{C}\right), R H$ is daily mean relative humidity in $\%$.

\subsection{ETo Method Evaluation Criteria}

Comparisons were developed using graphics and simple linear regression. For further comparison, root mean squared error (RMSE), relative error (RE), mean bias error (MBE) and the absolute mean error (AME) were used to evaluate the simplified reference evapotranspiration models [61] [62]:

$$
\begin{gathered}
\text { RMSE }=\sqrt{\sum_{i=0}^{n} \frac{(P i-O i)^{2}}{n}} \\
\mathrm{RE}=\frac{\text { RMSE }}{\text { ETomean }} \times 100 \\
\mathrm{MBE}=n^{-1} \sum_{1}^{n}(P i-O i) \\
\mathrm{AME}=n^{-1} \sum_{1}^{n}|P i-O i|
\end{gathered}
$$

where, $P i$ is the estimated ETo with the radiation based ETo models; and $O i$ is ETo estimated with FAO-PM model with full dataset, at the $i^{\text {th }}$ data point and $n$ is the total number of data points.

\section{Results and Discussion}

\subsection{Evaluation of the ETo Equations with Comparison to the FAO-PM Model}

The evaluation of the twelve mass transfer based ETo equations showed different degrees of performance of the equations with comparably reasonable coefficient of determination across the study area. The Brockamp-Wenner equation obtained the highest ETo overestimation with the RMSE ranging from 3.18 to 6.19 $\mathrm{mm} /$ day, an average relative error of $95 \%$ of ETo estimates and the highest AME range of 1.78 - $5.47 \mathrm{~mm} /$ day (Table 2). [30] indicated overestimation of ETo by mass transfer based equations, compared to the Penman-Monteith model similar to the results reported by [63]. [30] reported a maximum overestimate of 17.7 $\mathrm{mm}$ /day by the Albrecht equation in Iran. The Albrecht, Dalton, Meyer, Rohwer, and Oudin equations also systematically overestimated the daily ETo across the study area with an average regression slope of $1.323,1.288,1.218,1.263$ and 1.451 , respectively, and average $\mathrm{RE}$ of $71 \%, 41 \%, 34 \%, 41 \%$, and $52 \%$, respectively. The WMO and the Papadakis equations systematically underestimated the daily ETo at all weather stations. The RMSE varied from 1.09 to 1.97 $\mathrm{mm}$ /day and from 1.20 to $2.27 \mathrm{~mm}$ /day for WMO and the Papadaki equations, respectively (Table 2). The Penman, Mahringer, Trabert, and Romanenko equations overall showed satisfactory performance with some site specificities. The regression slope varied from 0.749 to $1.106,0.812$ to 1.15 , from 0.867 to 1.149 , and from 0.849 to 1.188 for the Penman, Mahringer, Trabert, and Romanenko equations, respectively, and averaged $0.929,0.957,1.017$, and 1.002 for the respective equations. The RMSE for these four equations averaged $0.98,1.38,1.48$, 
Table 2. Comparison between the ETo estimates by different mass transfer equation with FAO-PM ETo estimates at all nine weather stations for the 1998-2012 period.

\begin{tabular}{|c|c|c|c|c|c|c|c|c|c|c|c|c|c|}
\hline Index & Locations & Alb & Pen & B-W & $\mathrm{Dal}$ & Mah & Mey & Tra & WMO & Pap & Roh & Oud & Rom \\
\hline & Dodoma & 1.951 & 0.806 & 2.094 & 1.400 & 1.150 & 1.285 & 1.236 & 0.942 & 0.638 & 1.423 & 1.407 & 0.988 \\
\hline & Morogoro & 0.929 & 1.061 & 1.524 & 1.317 & 0.806 & 1.281 & 0.867 & 0.680 & 0.750 & 1.267 & 1.601 & 1.090 \\
\hline & Songea & 1.458 & 0.895 & 1.813 & 1.266 & 0.983 & 1.186 & 1.056 & 0.682 & 0.627 & 1.263 & 1.429 & 0.996 \\
\hline & Kilimanjaro & 1.625 & 1.081 & 2.108 & 1.498 & 1.139 & 1.412 & 1.123 & 0.903 & 0.759 & 1.486 & 1.609 & 1.089 \\
\hline \multirow[t]{10}{*}{ Regression slope } & Tabora & 1.397 & 1.106 & 1.992 & 1.472 & 1.068 & 1.403 & 1.149 & 0.812 & 0.779 & 1.444 & 1.684 & 1.188 \\
\hline & Nakuru & 1.121 & 0.923 & 1.642 & 1.218 & 0.879 & 1.164 & 0.945 & 0.688 & 0.560 & 1.192 & 1.404 & 0.902 \\
\hline & Jomo Kenyatta & 1.178 & 0.806 & 1.163 & 1.132 & 0.879 & 1.063 & 0.945 & 0.695 & 0.566 & 1.128 & 1.306 & 0.849 \\
\hline & Kisumu & 1.141 & 0.936 & 1.170 & 1.236 & 0.894 & 1.181 & 0.962 & 0.700 & 0.660 & 1.121 & 1.415 & 0.916 \\
\hline & Eldoret & 1.108 & 0.749 & 1.500 & 1.052 & 0.812 & 0.988 & 0.874 & 0.644 & 0.525 & 1.047 & 1.202 & 1.000 \\
\hline & rage & 1.323 & 0.929 & 1.667 & 1.288 & 0.957 & 1.218 & 1.017 & 0.750 & 0.652 & 1.263 & 1.451 & 1.002 \\
\hline & Dodoma & 0.55 & 0.70 & 0.69 & 0.75 & 0.68 & 0.76 & 0.78 & 0.66 & 0.69 & 0.73 & 0.71 & 0.65 \\
\hline & Morogoro & 0.33 & 0.53 & 0.47 & 0.63 & 0.46 & 0.63 & 0.46 & 0.54 & 0.51 & 0.63 & 0.42 & 0.43 \\
\hline & Songea & 0.48 & 0.68 & 0.62 & 0.67 & 0.61 & 0.68 & 0.61 & 0.60 & 0.67 & 0.66 & 0.66 & 0.61 \\
\hline & Kilimanjaro & 0.55 & 0.80 & 0.72 & 0.79 & 0.71 & 0.80 & 0.71 & 0.70 & 0.79 & 0.78 & 0.77 & 0.67 \\
\hline \multirow[t]{10}{*}{$\mathrm{R} 2$} & Tabora & 0.44 & 0.64 & 0.58 & 0.64 & 0.57 & 0.65 & 0.57 & 0.58 & 0.63 & 0.64 & 0.65 & 0.58 \\
\hline & Nakuru & 0.39 & 0.58 & 0.52 & 0.58 & 0.51 & 0.58 & 0.51 & 0.52 & 0.57 & 0.57 & 0.60 & 0.50 \\
\hline & Jomo Kenyatta & 0.55 & 0.73 & 0.70 & 0.74 & 0.69 & 0.74 & 0.69 & 0.67 & 0.72 & 0.73 & 0.74 & 0.68 \\
\hline & Kisumu & 0.41 & 0.60 & 0.55 & 0.60 & 0.54 & 0.61 & 0.54 & 0.54 & 0.59 & 0.59 & 0.62 & 0.52 \\
\hline & Eldoret & 0.42 & 0.67 & 0.57 & 0.62 & 0.56 & 0.64 & 0.56 & 0.53 & 0.67 & 0.60 & 0.70 & 0.70 \\
\hline & rage & 0.46 & 0.66 & 0.60 & 0.67 & 0.59 & 0.68 & 0.60 & 0.59 & 0.65 & 0.66 & 0.65 & 0.59 \\
\hline & Dodoma & 5.95 & 0.81 & 6.19 & 2.40 & 1.45 & 1.79 & 1.81 & 1.09 & 1.99 & 2.56 & 2.35 & 0.80 \\
\hline & Morogoro & 2.73 & 0.88 & 3.42 & 1.74 & 1.67 & 1.57 & 1.67 & 1.62 & 1.20 & 1.62 & 2.79 & 1.00 \\
\hline & Songea & 3.20 & 0.84 & 4.00 & 1.61 & 1.14 & 1.29 & 1.25 & 1.32 & 1.66 & 1.65 & 2.11 & 0.90 \\
\hline & Kilimanjaro & 4.36 & 0.83 & 5.77 & 2.67 & 1.49 & 2.24 & 1.79 & 1.21 & 1.26 & 2.67 & 3.07 & 0.96 \\
\hline \multirow[t]{10}{*}{ RMSE } & Tabora & 3.63 & 1.18 & 5.56 & 2.78 & 1.58 & 2.43 & 1.81 & 1.42 & 1.31 & 2.71 & 3.63 & 1.62 \\
\hline & Nakuru & 2.29 & 0.93 & 3.77 & 1.64 & 1.32 & 1.40 & 1.30 & 1.76 & 1.80 & 1.58 & 2.23 & 0.96 \\
\hline & Jomo Kenyatta & 2.29 & 1.05 & 3.18 & 1.08 & 1.02 & 0.86 & 0.96 & 1.55 & 1.99 & 1.10 & 1.59 & 0.91 \\
\hline & Kisumu & 2.27 & 0.89 & 3.80 & 1.66 & 1.25 & 1.41 & 1.25 & 1.68 & 1.73 & 1.60 & 2.28 & 0.92 \\
\hline & Eldoret & 2.87 & 1.39 & 3.21 & 1.32 & 1.52 & 1.14 & 1.47 & 1.97 & 2.27 & 1.39 & 1.39 & 0.86 \\
\hline & rage & 3.29 & 0.98 & 4.32 & 1.88 & 1.38 & 1.57 & 1.48 & 1.51 & 1.69 & 1.88 & 2.38 & 0.99 \\
\hline & Dodoma & 113.81 & 15.43 & 118.50 & 45.95 & 27.67 & 34.26 & 34.57 & 20.92 & 38.00 & 48.92 & 45.02 & 15.26 \\
\hline & Morogoro & 67.62 & 21.75 & 84.95 & 43.13 & 41.43 & 38.84 & 41.38 & 40.19 & 29.68 & 40.20 & 69.21 & 24.81 \\
\hline & Songea & 77.01 & 20.24 & 96.51 & 38.92 & 27.46 & 31.17 & 30.06 & 31.92 & 40.05 & 39.79 & 50.89 & 21.69 \\
\hline & Kilimanjaro & 94.81 & 18.06 & 125.48 & 58.13 & 32.47 & 48.59 & 39.00 & 26.19 & 27.36 & 58.07 & 66.69 & 20.81 \\
\hline \multirow[t]{5}{*}{$\mathrm{RE}$} & Tabora & 76.31 & 24.87 & 116.81 & 58.52 & 33.17 & 51.09 & 38.04 & 29.87 & 27.55 & 56.89 & 76.23 & 33.98 \\
\hline & Nakuru & 48.09 & 19.65 & 79.28 & 34.43 & 27.80 & 29.38 & 27.39 & 36.94 & 37.75 & 33.32 & 46.96 & 20.27 \\
\hline & Jomo Kenyatta & 52.39 & 23.96 & 72.74 & 24.65 & 23.32 & 19.62 & 21.98 & 35.40 & 45.46 & 25.16 & 36.38 & 20.75 \\
\hline & Kisumu & 48.39 & 18.97 & 81.16 & 35.40 & 26.76 & 30.17 & 26.63 & 35.85 & 36.82 & 34.15 & 48.69 & 19.54 \\
\hline & Eldoret & 63.02 & 30.49 & 70.55 & 28.94 & 33.46 & 25.04 & 32.19 & 43.15 & 49.90 & 30.51 & 30.54 & 18.77 \\
\hline
\end{tabular}




\section{Continued}

\begin{tabular}{|c|c|c|c|c|c|c|c|c|c|c|c|c|c|}
\hline & Average & 71.27 & 21.49 & 94.00 & 40.90 & 30.40 & 34.24 & 32.36 & 33.38 & 36.95 & 40.78 & 52.29 & 21.76 \\
\hline & Dodoma & 4.57 & -0.47 & 5.47 & 1.98 & 0.64 & 1.40 & 1.08 & -0.44 & -1.91 & 2.08 & 2.13 & -0.08 \\
\hline & Morogoro & -0.67 & 0.27 & 1.78 & 1.22 & -0.97 & 1.10 & -0.74 & -1.40 & -0.98 & 0.99 & 2.52 & 0.41 \\
\hline & Songea & 1.56 & -0.48 & 3.12 & 0.98 & -0.21 & 0.67 & 0.08 & -1.03 & -1.58 & 0.95 & 1.75 & -0.06 \\
\hline & Kilimanjaro & 2.28 & 0.33 & 4.69 & 2.11 & 0.40 & 1.76 & 0.78 & -0.65 & -1.13 & 2.03 & 2.84 & 0.43 \\
\hline \multirow[t]{10}{*}{ MBE } & Tabora & 1.47 & 0.43 & 4.36 & 2.07 & 0.12 & 1.77 & 0.49 & -0.91 & -1.10 & 1.92 & 3.18 & 0.80 \\
\hline & Nakuru & 0.36 & -0.41 & 2.86 & 0.94 & -0.68 & 0.70 & -0.38 & -1.56 & -1.69 & 0.81 & 1.90 & -0.48 \\
\hline & Jomo Kenyatta & 0.94 & -0.90 & 2.51 & 0.47 & -0.65 & 0.18 & -0.37 & -1.44 & -1.93 & 0.43 & 1.31 & -0.68 \\
\hline & Kisumu & 0.44 & -0.34 & 2.94 & 1.01 & -0.61 & 0.77 & -0.30 & -1.49 & -1.63 & 0.88 & 1.97 & -0.41 \\
\hline & Eldoret & 0.46 & -1.23 & 1.95 & 0.06 & -1.04 & -0.21 & -0.77 & -1.77 & -2.22 & 0.02 & 0.82 & -0.08 \\
\hline & Average & 1.27 & -0.31 & 3.30 & 1.20 & -0.33 & 0.91 & -0.02 & -1.19 & -1.58 & 1.12 & 2.04 & -0.02 \\
\hline & Dodoma & 4.98 & 0.67 & 5.57 & 2.04 & 1.15 & 1.49 & 1.48 & 0.86 & 1.91 & 2.17 & 2.14 & 0.63 \\
\hline & Morogoro & 2.03 & 0.69 & 2.70 & 1.38 & 1.34 & 1.26 & 1.30 & 1.47 & 1.03 & 1.24 & 2.55 & 0.77 \\
\hline & Songea & 2.18 & 0.68 & 3.22 & 1.21 & 0.88 & 0.98 & 0.95 & 1.16 & 1.58 & 1.22 & 1.79 & 0.74 \\
\hline & Kilimanjaro & 2.91 & 0.63 & 4.76 & 2.18 & 1.10 & 1.83 & 1.30 & 1.02 & 1.15 & 2.11 & 2.85 & 0.74 \\
\hline \multirow[t]{6}{*}{ MBE } & Tabora & 2.46 & 0.95 & 4.52 & 2.19 & 1.23 & 1.91 & 1.40 & 1.21 & 1.16 & 2.09 & 3.19 & 1.29 \\
\hline & Nakuru & 1.55 & 0.77 & 2.97 & 1.12 & 1.08 & 0.94 & 1.00 & 1.63 & 1.70 & 1.06 & 1.91 & 0.81 \\
\hline & Jomo Kenyatta & 1.61 & 0.93 & 2.56 & 0.80 & 0.88 & 0.65 & 0.80 & 1.46 & 1.93 & 0.81 & 1.35 & 0.78 \\
\hline & Kisumu & 1.52 & 0.72 & 3.03 & 1.15 & 1.02 & 0.96 & 0.95 & 1.56 & 1.63 & 1.08 & 1.97 & 0.76 \\
\hline & Eldoret & 1.84 & 1.29 & 2.19 & 0.90 & 1.36 & 0.85 & 1.26 & 1.85 & 2.22 & 0.96 & 0.96 & 0.62 \\
\hline & Average & 2.34 & 0.82 & 3.50 & 1.44 & 1.11 & 1.21 & 1.16 & 1.36 & 1.59 & 1.42 & 2.08 & 0.79 \\
\hline
\end{tabular}

and $0.99 \mathrm{~mm} /$ day (Table 2), however, they had low corresponding magnitude of $\mathrm{RE}, \mathrm{MBE}$ and AME compared to the Brockamp-Wenner, Albrecht, Dalton, Meyer, Rohwer, and Oudin equations.

The results indicate that there is site specific adaptability of the ETo equations under this study. The Albrecht equation showed the best performance at Morogoro. The Penman equation seems to be non-applicable only at Dodoma, Jomo Kenyatta and Eldoret weather stations, however with site calibration the performance of the Penman equation could be improved and the adjusted Penman equation may be applicable across the study area. The Dalton equation showed its best performance at Eldoret while the Mahringer equation is adapted to the Songea station and the Trabert equation could be used at Songea, Nakuru, Jomo Kenyatta, and Kisumu stations. The Rohwer equation showed the best performance at Eldoret and the Romanenko equation performed satisfactorily at all weather stations, except Tabora and Jomo Kenyatta weather stations. Overall, the best four ETo equations can be ranked as Romanenko, Penman, Trabert and Mahringer with a decreasing performance levels. The Romanenko and Penman equations had almost similar performance in terms of RMSE, MBE and AME (Table 2). The Trabert and Mahringer equations also showed similar performance. The Penman equation was the best performing equation among mass transfer equations across 15 provinces in Iran with the least ETo overestimate of 
$0.03 \mathrm{~mm} /$ day as the Papadakis equation [30] [40]. [2] reported that the Romanenko equation showed better performance under dry and semiarid condition than under the humid semiarid conditions in the Senegal River Valley. Romanenko equation produced a $6 \%$ ETo underestimation and obtained a mean ratio of 1.0 and a regression slope of 0.92 [2]. Similarly in Iran, the Romanenko equation was reported as the best mass transfer equation [19]. The Trabert and Mahringer equations performed relatively well under the sahelian climatic conditions as reported by [2]. [19] reported that Trabert and Mahringer equations underestimated ETo with average error of $26 \%$ and $31 \%$, respectively in Iran while [2] reported average ETo underestimation of $16 \%$ and $31 \%$ at Ndiaye (coastal area) and at Fanaye (inland area) in the Senegal River Valley and Delta, respectively. [64] reported the FAO24-Radiation method to be the best among twenty ETo equations evaluated in the sub-humid Udham Singh Nagar district of Uttarakhand (India). Adversely, poor performance of the Mahringer equation was reported in Poland [42]. [38] indicated reasonable performance of the Meyer, Dalton, and Rohwer equation for free water evaporation estimation from four weather stations in north-western Ontario, Canada. The results of this study showed the specificity of each ETo equation and this might have been due to the sensitivity of the models to the climatic variables used in each model [30].

\subsection{ETo Equation Adoption for Sustainable Water Management across the Study Area}

Reference evapotranspiration is a very important parameter for the hydrological, environmental and agricultural water management and it is much critical under water scarcity and changing climate conditions under semiarid and arid climates. Crop actual evapotranspiration (ETa) is indirectly estimated by the two steps method as a product of daily ETo and the crop coefficients Kc that is dependent on crop type and growth stages, climate, soil type, crop and water management practices and other environmental conditions $\left(\mathrm{ETa}=\mathrm{Kc}^{\star} \mathrm{ETo}\right)$ [6] [65] [66]. The effectiveness of this procedure depends upon the accuracy of data collection and ETo estimation method used. Since crop water requirement is dependent on ETo it is necessary to evaluate the impact of the choice of ETo estimation method on water resources management at local scale. The impact of using each ETo equation for water management at all weather stations is presented in Figure 1 showing the large discrepancies between the ETo estimates by the FAO-PM equation and the mass transfer ETo equations during the period of 1998 to 2012. As a selection criterion for sustainable water management, the model showing the closest cumulative ETo estimate to the cumulative FAO-PM ETo estimate (Figure 1) should be adopted for that location. Average annual total ETo estimates difference of each mass transfer ETo equation at each weather station relative to the FAO-PM ETo estimates is presented in Table 3. At Dodoma, annual average ETo difference varied from -697 to $1997 \mathrm{~mm}$ with the highest overestimation by the Brockamp-Wenner equation while the lowest annual absolute difference of $29 \mathrm{~mm}$ representing ETo underestimation of 0.08 

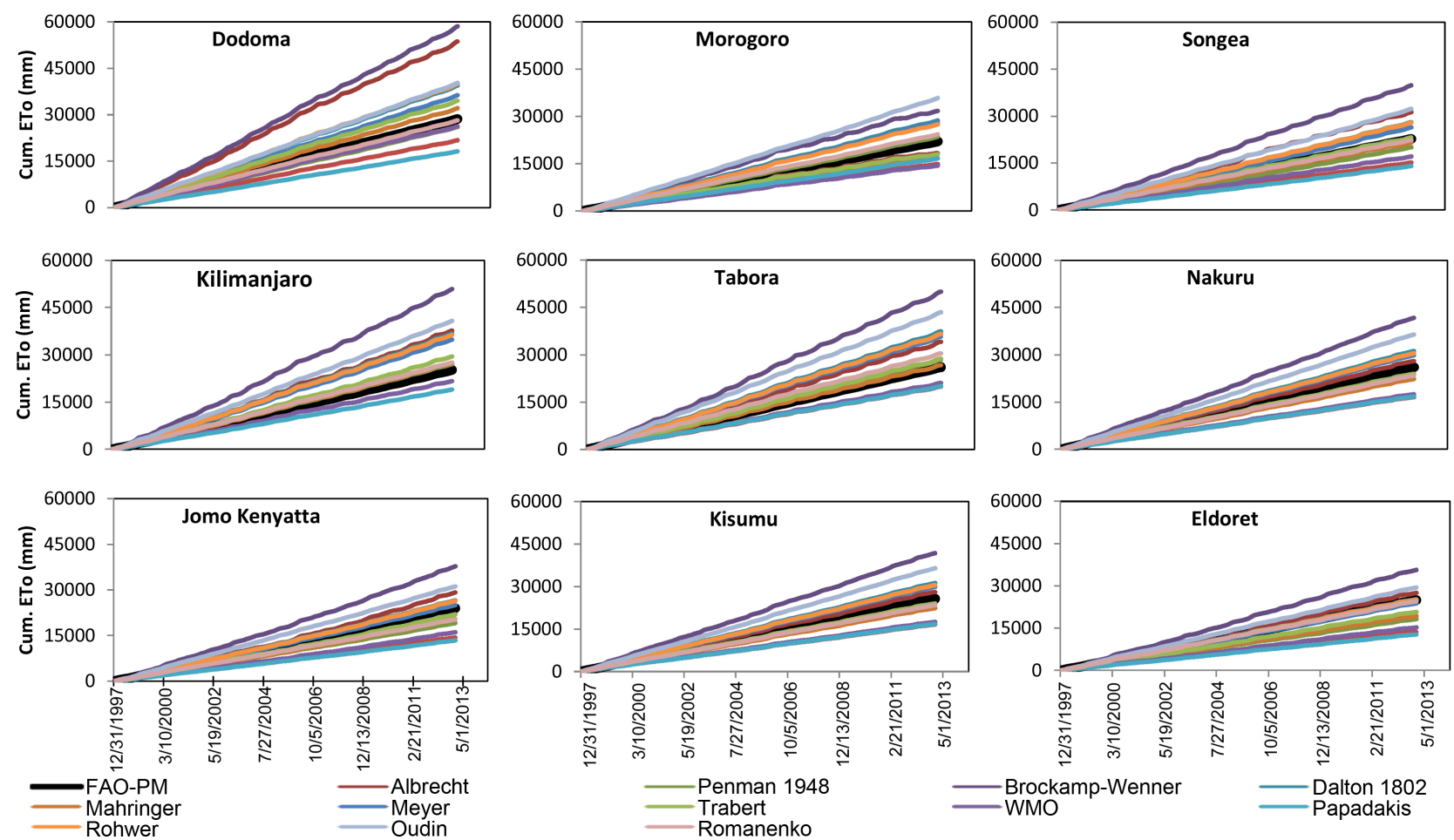

Figure 1. Long-term cumulative daily ETo estimated from the mass transfer equations with comparison to the FAO-PM equation.

Table 3. The 1998-2012 period average total annual ETo difference between the mass transfer ETo equations and the FAO-PM equation at all nine weather stations.

\begin{tabular}{ccccccccccccc}
\hline Locations & Alb & Pen & B-W & Dal & Mah & Mey & Tra & WMO & Pap & Roh & Oud & Rom \\
\hline Dodoma & 1671 & -171 & 1997 & 722 & 233 & 512 & 394 & -159 & -697 & 759 & 777 & -29 \\
Morogoro & -245 & 99 & 649 & 444 & -355 & 403 & -271 & -511 & -360 & 362 & 919 & 151 \\
Songea & 569 & -176 & 1141 & 357 & -78 & 245 & 31 & -375 & -576 & 346 & 639 & -24 \\
Kilimanjaro & 833 & 121 & 1712 & 772 & 147 & 642 & 284 & -236 & -414 & 741 & 1037 & 158 \\
Tabora & 536 & 156 & 1593 & 755 & 44 & 647 & 178 & -334 & -404 & 701 & 1160 & 291 \\
Nakuru & 132 & -150 & 1046 & 344 & -249 & 255 & -137 & -571 & -619 & 297 & 693 & -174 \\
Jomo Kenyatta & 345 & -327 & 917 & 171 & -238 & 67 & -136 & -527 & -706 & 159 & 478 & -247 \\
Kisumu & 160 & -125 & 1075 & 369 & -222 & 281 & -110 & -546 & -594 & 322 & 718 & -150 \\
Eldoret & 170 & -450 & 714 & 21 & -379 & -77 & -282 & -648 & -812 & 8 & 298 & -29 \\
\hline
\end{tabular}

$\mathrm{mm} /$ day was obtained by the Romanenko ETo estimates. The original Romamenko mass transfer ETo equation can therefore be recommended for ETo estimation at Dodoma area for appropriate and sustainable water management. On the other hand our results suggest, that the Brockamp-Wenner, Albrecht, and the other ETo equations should be avoided when choosing ETo estimation method for the Dodoma area. The Penman equation provided the least annual ETo difference of $99 \mathrm{~mm}$ representing a reasonable daily ETo overestimation of $0.3 \mathrm{~mm}$ at Morogoro weather station and should be adopted for water management in Morogoro. Similarly, the Trabert and/or the Marhringer equations at 
Songea, the Marhinger, Penman at Kilimanjaro, the Mahringer equations at Tabora, the Meyer equation at Jomo Kenyatta and the Rohwer, Dalton and/or Romananko equations at Eldoret could be adopted at the respective locations with non-significant overestimation or underestimation of the annual ETo that could be detrimental to water resources management sustainability across Tanzania and the South Western Kenya. The least annual absolute ETo difference was 130 $\mathrm{mm}$ at Nakuru and $110 \mathrm{~mm}$ at Kisumu which represented 1300 and $1100 \mathrm{~m}^{3} / \mathrm{ha}$. Site specific calibration of the best performing ETo equation (Trabert equation) should be performed to improve the performance of the equation under the Kisumu and Nakuru climate conditions. Moreover, other ETo estimation models should be investigated for accurate ETo estimation at Kisumu and Nakuru. Alternatively, the FAO-PM equation or the Valiantzas equation with complete data could be used in place even under limited data conditions as proposed by [44] for the study area.

In cases of ETo overestimation, estimated irrigation water requirement becomes tremendously high and which will still increase when taking the low efficiency of the irrigation system into account. The Albrecht, Brockamp-Wenner, Dalton, Meyer, Rohwer and Oudin equation should be carefully investigated and adjusted through proper calibration across Tanzania and Kenya for sustainable water management since considerable discrepancies are revealed under long term water management as presented in Figure 1. At an irrigation scheme level and basin level, water losses become considerable and the implications in terms of pumping cost, labor and time requirements result in economically unviable products due to high pricing level that is unaffordable for the majority of small household farmers. In the case of ETo underestimation, there is a risk to put crops under water stress that will impact the yield and the quality of the harvested products and environmental pollution particularly soil pollution by nitrates [67]. The best performing ETo equation that could be adopted at a site is as the Mahringer equation at Tabora, the Trabert equation at Songea, the Rohwer equation at Eldoret and the Romanenko ETo equation at Dodoma, Songea and Eldoret (Table 3).

\section{Conclusion}

Performance of twelve mass transfer based reference evapotranspiration equations was investigated in comparison to the FAO-PM method for accurate ETo estimation across Tanzania and South Western Kenya and the impact of the use of each method on water management sustainability was assessed. The Albrecht, Brockamp-Wenner, Dalto, Meyer, Rohwer and Oudin ETo equations systematically overestimated the daily ETo at all nine weather stations with relative errors that varied from $34 \%$ to $94 \%$ relative to the FAO-PM ETo estimates. The Dalton, WMO, and Papadakis ETo equations systematically underestimated the daily ETo at all weather stations. The Penman, Mahringer, Trabert, and the Romanenko equations were revealed to be the best performing equations across Tan- 
zania and the South Western Kenya however, the root mean squared errors were within the range from 0.98 to $1.48 \mathrm{~mm} /$ day, which are relatively high and $\mathrm{MBE}$ varying from -0.33 to $0.02 \mathrm{~mm} /$ day and the AME from 0.79 to $1.16 \mathrm{~mm} /$ day. For sustainable water management, The Trabert equation could be adopted at Songea, the Mahringer equation at Tabora, the Dalton and/or the Rohwer equations at Eldoret, the Romanenko equation at Dodoma, Songea and Eldoret. The 15-year absolute cumulative daily ETo differences compared to the FAO-PM ETo estimates were only $99 \mathrm{~mm}$ with the Penman equation at Morogogo, $21 \mathrm{~mm}$ with the Dalton equation at Eldoret, $44 \mathrm{~mm}$ with the Mahringer equation at Tabora, $67 \mathrm{~mm}$ with the Meyer equation at Jomo Kenyatta, $31 \mathrm{~mm}$ with the Travert equation at Songea, $8 \mathrm{~mm}$ with the Rohwer equation at Eldoret, and 29, 24 and $20 \mathrm{~mm}$ with the Romanenko equation at Dodoma, Songea and Eldoret, respectively. However, regional or sub-regional calibration of the best performing Penman, Mahringer, Trabert and the Romanenko equation could improve water management in Tanzania and Kenya under the conservative and sustainable agriculture. This study provides a pragmatic solution for the region that can be used as a guide to choose which method(s) would be a reasonable alternative to estimate ETo when all climatic data are not available at particular locations. However, other reference evapotranspiration equations including the radiation based and the combination equations should tested to determine the best alternative ETo equation to the Penman-Monteith equation for sustainable water management in Tanzania and Kenya. Given the current status of weather station networks in the region, the results of this study can enhance crop water use estimation and thus feeds into the decision making process for regional water resources planning by irrigators, water managers and other agricultural professionals.

\section{References}

[1] Allen, R.G., Pereira, L.S., Howell, T.A. and Jensen, M.E. (2011) Evapotranspiration Information Reporting: II. Recommended Documentation. Agricultural Water Management, 98, 921-929. https://doi.org/10.1016/j.agwat.2010.12.016

[2] Djaman, K., Balde, A.B., Sow, A., Muller, B., Irmak, S., Ndiaye, M.K., Manneh, B., Moukoumbi, Y.D., Futakuchi, K. and Saito, K. (2015) Evaluation of Sixteen Reference Evapotranspiration Methods under Sahelian Conditions in the Senegal River Valley. Journal of Hydrology: Regional Studies, 3, 139-159.

[3] Doorenbos, J. and Pruitt, W.O. (1977) Guidelines for Predicting Crop Water Requirements. FAO Irrigation and Drainage Paper 24, FAO, Rome.

[4] Thornthwaite, C.W. (1948) An Approach towards a Rational Classification of Climate. Geographical Review, 38, 55-94. https://doi.org/10.2307/210739

[5] Hargreaves, G.H. and Samani, Z.A. (1985) Reference Crop Evapotranspiration from Temperature. Applied Engineering in Agriculture, 1, 96-99. https://doi.org/10.13031/2013.26773

[6] Allen, R.G., Pereira, L.S., Raes, D. and Smith, M. (1998) Crop Evapotranspiration: Guidelines for Computing Crop Water Requirements. FAO Irrigation and Drainage Paper No. 56, FAO, Rome. 
[7] ASCE-EWRI (2005) The ASCE Standardized Reference Evapotranspiration Equation. In: Allen, R.G., Walter, I.A., Elliot, R.L., et al., Eds., Standardization of Reference Evapotranspiration Task Committee Final Report, Environmental and Water Resources Institute (EWRI) of the American Society of Civil Engineers, American Society of Civil Engineers (ASCE), Reston, 213 p.

[8] Irmak, S., Irmak, A., Allen, R.G. and Jones, J.W. (2003) Solar and Net Radiation-Based Equations to Estimate Reference Evapotranspiration in Humid Climates. Journal of Irrigation and Drainage Engineering, 129, 336-347.

https://doi.org/10.1061/(ASCE)0733-9437(2003)129:5(336)

[9] Hargreaves, G.H. and Allen, R.G. (2003) History and Evaluation of Hargreaves Evapotranspiration Equation. Journal of Irrigation and Drainage Engineering, 129, 53-63. https://doi.org/10.1061/(ASCE)0733-9437(2003)129:1(53)

[10] Mendonça, J.C., Sousa, E.F., de Bernardo, S., Dias, G.P. and Grippa, S. (2003) Comparison of Estimation Methods of Reference Crop Evapotranspiration (ETo) for Northeren Region of Rio de Janeiro State, Brazil. Revista Brasileira de Engenharia Agrícola e Ambiental, 7, 275-279.

https://doi.org/10.1590/S1415-43662003000200015

[11] Garcia, M., Raes, D., Allen, R. and Herbas, C. (2004) Dynamics of Reference Evapotranspiration in the Bolivian Highlands (Altiplano). Agricultural Forest and Meteorology, 125, 67-82. https://doi.org/10.1016/j.agrformet.2004.03.005

[12] Utset, A., Farre, I., Martinez-Cob, A. and Cavero, J. (2004) Comparing Penman-Monteith and Priestley-Taylor Approaches as Reference Evapotranspiration Inputs for Modeling Maize Water Use under Mediterranean Conditions. Agricultural Water Management, 66, 205-219. https://doi.org/10.1016/j.agwat.2003.12.003

[13] López-Urrea, R., Martín de Santa Olalla, F., Fabeiro, C. and Moratalla, A. (2006) Testing Evapotranspiration Equations Using Lysimeter Observations in a Semiarid Climate. Agricultural Water Management, 85, 15-26. https://doi.org/10.1016/j.agwat.2006.03.014

[14] Stockle, C.O., Kjelgaard, J. and Bellocchi, G. (2004) Evaluation of Estimated Weather Data for Calculating Penman-Monteith Reference Crop Evapotranspiration. Irrigation Science, 23, 39-46. https://doi.org/10.1007/s00271-004-0091-0

[15] Todorovic, M., Karic, B. and Pereira, L.S. (2013) Reference Evapotranspiration Estimate with Limited Weather Data across a Range of Mediterranean Climates. Journal of Hydrology, 481, 166-176. https://doi.org/10.1016/j.jhydrol.2012.12.034

[16] Li, Z., Zheng, F.L and Liu, W.Z. (2012) Spatiotemporal Characteristics of Reference Evapotranspiration during 1961-2009 and Its Projected Changes during 2011-2099 on the Loess Plateau of China. Agricultural and Forest Meteorology, 154-155, 147-155. https://doi.org/10.1016/j.agrformet.2011.10.019

[17] Rahimikhoob, A., Behbahani, M.R. and Fakheri, J. (2012) An Evaluation of Four Reference Evapotranspiration Models in a Subtropical Climate. Water Resources Management, 26, 2867-2881. https://doi.org/10.1007/s11269-012-0054-9

[18] Martinez, C.J. and Thepadia, M. (2010) Estimating Reference Evapotranspiration with Minimum Data in Florida, USA. Journal of Irrigation and Drainage Engineering, 136, 494-501. https://doi.org/10.1061/(ASCE)IR.1943-4774.0000214

[19] Tabari, H., Grismer, M. and Trajkovic, S. (2011a) Comparative Analysis of 31 Reference Evapotranspiration Methods under Humid Conditions. Irrigation Science, 31, 107-117. https://doi.org/10.1007/s00271-011-0295-Z

[20] Blaney, H.F. and Criddle, W.D. (1962) Determining Consumptive Use and Irrigation Water Requirements. USDA Technical Bulletin 1275, US Department of Agri- 
culture, Beltsville.

[21] Snyder, R.L. (1992) Equation for Evaporation Pan to Evapotranspiration Conversions. Journal of Irrigation and Drainage Engineering, 118, 977-980. https://doi.org/10.1061/(ASCE)0733-9437(1992)118:6(977)

[22] Xystrakis, F. and Matzarakis, A. (2011) Evaluation of 13 Empirical Reference Potential Evapotranspiration Equations on the Island of Crete in Southern Greece. Journal of Irrigation and Drainage Engineering, 137, 211-222. https://doi.org/10.1061/(ASCE)IR.1943-4774.0000283

[23] Valiantzas, J.D. (2013a) Simplified Forms for the Standardized FAO-56 Penman-Monteith Reference Evapotranspiration Using Limited Data. Journal of $\mathrm{Hy}$ drology, 505, 13-23. https://doi.org/10.1016/j.jhydrol.2013.09.005

[24] Valiantzas, J.D. (2013b) Simplified Reference Evapotranspiration Formula Using an Empirical Impact Factor for Penman's Aerodynamic Term. Journal of Irrigation and Drainage Engineering, 18, 108-114. https://doi.org/10.1061/(ASCE)HE.1943-5584.0000590

[25] Droogers, P. and Allen, R.G. (2002) Estimating Reference Evapotranspiration under Inaccurate Data Conditions. Irrigation Drainage System, 16, 33-45. https://doi.org/10.1023/A:1015508322413

[26] Yoder, R.E., Odhiambo, L.O. and Wright, W.C. (2005) Evaluation of Methods for Estimating Daily Reference Crop Evapotranspiration at a Site in the Humid Southeast United States. Applied Engineering in Agriculture, 21, 197-202. https://doi.org/10.13031/2013.18153

[27] Xing, Z., Chow, L., Meng, F., Rees, H.W., Monteith, J. and Lionel, S. (2008) Testing Reference Evapotranspiration Estimation Methods Using Evaporation Pan and Modeling in Maritime Region of Canada. Journal of Irrigation and Drainage Engineering, 134, 417-424. https://doi.org/10.1061/(ASCE)0733-9437(2008)134:4(417)

[28] Tabari, H. and Hosseinzadeh-Talaee, P. (2011b) Temporal Variability of Precipitation over Iran: 1966-2005. Journal of Hydrology, 396, 313-320. https://doi.org/10.1016/j.jhydrol.2010.11.034

[29] Liou, Y.-A. and Kar, S.K. (2014) Evapotranspiration Estimation with Remote Sensing and Various Surface Energy Balance Algorithms. A Review. Energies, 7, 2821-2849. https://doi.org/10.3390/en7052821

[30] Valipour, M. (2014) Investigation of Valiantzas' Evapotranspiration Equation in Iran. Theoretical and Applied Climatology, 121, 1-2.

[31] Sabziparvar, A.A. and Tabari H. (2010) Regional Estimation of Reference Evapotranspiration in Arid and Semi-Arid Regions. Journal of Irrigation and Drainage Engineering, 136, 724-731. https://doi.org/10.1061/(ASCE)IR.1943-4774.0000242

[32] Trajkovic, S. and Kolakovic, S. (2009) Evaluation of Reference Evapotranspiration Equations under Humid Conditions. Water Resource Management, 23, 3057-3067. https://doi.org/10.1007/s11269-009-9423-4

[33] Bourletsikas, A., Argyrokastritis, I. and Proutsos, N. (2017) Comparative Evaluation of 24 Reference Evapotranspiration Equations Applied on an Evergreen-Broadleaved Forest. Hydrology Research, Online.

[34] Peng, L., Yi, L. and Hao, F. (2017) The Best Alternative for Estimating Reference Crop Evapotranspiration in Different Sub-Regions of Mainland China. Scientific Reports, 7, 5458. https://doi.org/10.1038/s41598-017-05660-y

[35] Djaman, K., Tabari, H., Balde, A.B., Diop, L., Futakuchi, K. and Irmak, S. (2016) Analyses, Calibration and Validation of Evapotranspiration Models to Predict Grass 
reference Evapotranspiration in the Senegal River Delta. Journal of Hydrology: Regional Studies, 8, 82-94. https://doi.org/10.1016/j.ejrh.2016.06.003

[36] Muniandy, J., Zulkifli, Y. and Muhamad, A. (2016) Evaluation of Reference Evapotranspiration Models and Determination of Crop Coefficient for Momordica charantia and Capsicum annuum. Agricultural Water Management, 169, 77-89. https://doi.org/10.1016/j.agwat.2016.02.019

[37] Ndiaye, P.M., Bodian, A., Diop, L. and Djaman, K. (2017) Evaluation de vingt méthodes d'estimation de l'évapotranspiration journalière de référence au Burkina Faso. [Evaluation of Twenty Daily Reference Evapotranspiration Methods in Burkina Faso.] Physio-Geo, 11-1, 129-146. https://doi.org/10.4000/physio-geo.5369

[38] Singh, V.P. and Xu, C.Y. (1997) Evaluation and Generalization of 13 Mass Transfer Equations for Determining Free Water Evaporation. Hydrological Processes, 11, 311-323.

https://doi.org/10.1002/(SICI)1099-1085(19970315)11:3<311::AID-HYP446>3.0.CO ;2-Y

[39] Heydari, M.M. and Heydari, M. (2014) Evaluation of Pan Coefficient Equations for Estimating Reference Crop Evapotranspiration in the Arid Region. Archives of Agronomy and Soil Science, 60, 715-731.

https://doi.org/10.1080/03650340.2013.830286

[40] Valipour, M. (2015) Importance of Solar Radiation, Temperature, Relative Humidity, and Wind Speed for Calculation of Reference. Archives of Agronomy and Soil Science, 6, 239-255.

[41] Zhai, L., Feng, Q., Li, Q. and Xu, C. (2010) Comparison and Modification of Equations for Calculating Evapotranspiration (ET) with Data from Gansu Province, Northwest China. Irrigation and Drainage, 59, 477-490. https://doi.org/10.1002/ird.502

[42] Bogawski, P. and Bednorz, E. (2014) Comparison and Validation of Selected Evapotranspiration Models for Conditions in Poland (Central Europe). Water Resources Management, 28, 5021-5038. https://doi.org/10.1007/s11269-014-0787-8

[43] Azhar, A.H. and Perera, B.J.C. (2011) Evaluation of Reference Evapotranspiration Estimation Methods under Southeast Australian Conditions. Journal of Irrigation and Drainage Engineering, 137, 268-279. https://doi.org/10.1061/(ASCE)IR.1943-4774.0000297

[44] Djaman, K., Irmak, S., Kabenge, I. and Futakuchi, K. (2016) Evaluation of the FAO-56 Penman-Monteith Model with Limited Data and the Valiantzas Models for Estimating Reference Evapotranspiration in the Sahelian Conditions. Journal of Irrigation and Drainage Engineering, 142, Article ID: 04016044.

https://doi.org/10.1061/(ASCE)IR.1943-4774.0001070

[45] McSweeney, C., New, M. and Lizcano, G. (2010a) UNDP Climate Change Country Profiles: Kenya. https://digital.library.unt.edu/ark:/67531/metadc226624/

[46] McSweeney, C., New, M., Lizcano, G. and Lu, X. (2010b) The UNDP Climate Change Country Profiles Improving the Accessibility of Observed and Projected Climate Information for Studies of Climate Change in Developing Countries. Bulletin of the American Meteorological Society, 91, 157-166. https://doi.org/10.1175/2009BAMS2826.1

[47] King'uyu, S.M., Kilavi, M., Omeny, P., Muigai, E. and Njogu, A.K. (2011) Climate Change Indices for Kenya. Journal of Meteorology and Related Sciences, 5, 49-55.

[48] McSweeney, C., New, M. and Lizcano, G. (2010c) UNDP Climate Change Country 
Profiles: Tanzania.

http://www.geog.ox.ac.uk/research/climate/projects/undp-cp/UNDP_reports/Tanza nia/Tanzania.lowres.report.pdf

[49] Dalton, J. (1802) Experimental Essays on the Constitution of Mixed Gases: On the Force of Steam or Vapour from Water or Other Liquids in Different Temperatures, Both in a Torricelli Vacuum and in Air; on Evaporation; and on Expansion of Gases by Heat. Memoirs of the Literary and Philosophical Society of Manchester, 5, 536-602.

[50] Trabert, W. (1896) Neue Beobachtungenûber Verdampfungsgeschwindigkeiten. [New Observations on Evaporation Rates.] Meteorologische Zeitschrift, 13, 261-263

[51] Meyer, A. (1926) Uber einige Zusammenha ngezwischen Klima und Boden in Europa. [Some Interrelations between Climate and Soil in Europe.] Chemie der Erde, 2, 209-347.

[52] Rohwer, C. (1931) Evaporation from Free Water Surfaces. Technical Bulletin 271, US Department of Agriculture, Washington DC.

[53] Penman, H.L. (1948) Natural Evaporation from Open Water, Bare Soil and Grass. Proceedings of the Royal Society of London, 193, 120-145.

https://doi.org/10.1098/rspa.1948.0037

[54] Albrecht, F. (1950) Die Methodenzur Bestimmung der Verdunstungdernaturlichen Erdoberflache. [Evaporation Estimation Methods for Natural Earth's Surface.] Arch Meteor Geoph. BioklSer, B, 2, 1-38.

[55] Romanenko, V.A. (1961) 'Computation of the Autumn Soil Moisture Using a Universal Relationship for a Large Area. Ukrainian Hydrometeorological Research Institute, Kiev, No. 3.

[56] Brockamp, B. and Wenner, H. (1963) Verdunstungsmessungen auf den Steiner See bei Munster. [Evaporation Measurements on the Steiner Lake at Munster.] Deutsche gewässerkundliche Mitteilungen, 7, 149-154.

[57] World Meteorological Organization (WMO) (1966) Measurement and Estimation of Evaporation and Evapotranspiration. Tech Pap (CIMO-Rep) 83, WMO, Genf.

[58] Papadakis, J. (1966) Climates of the World and Their Agricultural Potentialities. Eigenverl. d. Verf., Buenos Aires.

[59] Mahringer, W. (1970) Verdunstungsstudien am Neusiedler See. [Evaporation Studies at Lake Neusiedl.] Arch Met GeophBioklSer, B, 18, 1-20.

[60] Oudin, L., Hervieu, F., Michel, C., Perrin, C., Andreassian, V., Anctil, F. and Loumagne, C. (2005) Which Potential Evapotranspiration in Put for a Lumped Rainfall-Runoff Model? Part 2-Towards a Simple and Efficient Potential Evapotranspiration Model for Rainfall-Runoff Modelling. Journal of Hydrology, 303, 290-306. https://doi.org/10.1016/j.jhydrol.2004.08.026

[61] Makridakis, S., Wheelwright, S.C. and Megee, V.E. (1986) Forecasting: Methods and Application. 2nd Edition, Wiley, New York.

[62] Helsel, D.R. and Hirsch, R.M. (1991) Statistical Methods in Water Resources. Book 4, US Geological Survey, $522 \mathrm{p}$.

[63] Winter, T.C., Rosenberry, D.O. and Sturrock, A.M. (1995) Evaluation of 11 Equations for Determining Evaporation for a Small Lake in the North Central United States. Water Resources Research, 31, 983-993. https://doi.org/10.1029/94WR02537

[64] Tomar, A.S. (2015) Comparative Performance of Reference Evapotranspiration Equations at Sub-Humid Tarai Region of Uttarakhand, India. International Journal of 
Agricultural Research, 10, 65-73. https://doi.org/10.3923/ijar.2015.65.73

[65] Irmak, S. and Mutiibwa, D. (2010) On the Dynamics of Canopy Resistance: Generalized-Linear Estimation and Relationships with Primary Micrometeorological Variables. Water Resources Research, 46, 1-20, W08526.

[66] Djaman, K. and Irmak, S. (2013) Actual Crop Evapotranspiration and Alfalfa- and Grass-Reference Crop Coefficients of Maize under Full and Limited Irrigation and Rainfed Conditions. Journal of Irrigation and Drainage Engineering, 139, 433-446. https://doi.org/10.1061/(ASCE)IR.1943-4774.0000559

[67] Djaman, K., Irmak, S., Martin, D.L., Ferguson, R.B. and Bernards, M.L. (2013) Plant Nutrient (N, P, K) Uptake, Grain Nutrient Content, and Soil Nutrient Dynamics under Full and Limited Irrigation and Rainfed Maize Production. Agronomy Journal, 105, 527-538. https://doi.org/10.2134/agronj2012.0269 